\title{
Effect of Different Cleansers on the Surface of Removable Partial Denture
}

\author{
Daniela Nair Borges FELIPUCCI ${ }^{1}$ \\ Letícia Resende DAVI ${ }^{1}$ \\ Helena Freitas Oliveira PARANHOS ${ }^{1}$ \\ Osvaldo Luiz BEZZON ${ }^{1}$ \\ Rodrigo Ferreira SILVA ${ }^{2}$ \\ Valéria Oliveira PAGNANO \\ ${ }^{1}$ Department of Dental Materials and Prosthodontics, Ribeirão Preto Dental School, \\ USP - University of São Paulo, Ribeirão Preto, SP, Brazil \\ ${ }^{2}$ Department of Chemistry, School of Philosophy, Sciences and Languages, \\ USP - University of São Paulo, Ribeirão Preto, SP, Brazil
}

\begin{abstract}
Removable partial dentures (RPD) demand specific hygienic cleaning and the combination of brushing with immersion in chemical solutions has been the most recommended method for control of biofilm. However, the effect of the cleansers on metallic components has not been widely investigated. This study evaluated the effect of different cleansers on the surface of RPD. Five disc specimens (12 mm x $3 \mathrm{~mm}$ metallic disc centered in a $38 \times 18 \times 4 \mathrm{~mm}$ mould filled with resin) were obtained for each experimental situation: 6 solutions [Periogard (PE), Cepacol (CE), Corega Tabs (CT), Medical Interporous (MI), Polident (PO), 0.05\% sodium hypochlorite $(\mathrm{NaOCl})$, and distilled water (DW) control] and $2 \mathrm{Co}-\mathrm{Cr}$ alloys [DeguDent (DD) and VeraPDI (VPDI)] were used for each experimental situation. A 180-day immersion was simulated and the measurements of roughness $(R a, \mu \mathrm{m})$ of metal and resin were analyzed using 2-way ANOVA and Tukey's test. The surface changes and tarnishes were examined with a scanning electronic microscopy (SEM). In addition, energy dispersive x-ray spectrometry (EDS) analysis was carried out at representative areas. Visually, $\mathrm{NaOCl}$ and $\mathrm{MI}$ specimens presented surface tarnishes. The roughness of materials was not affected by the solutions ( $p>0.05)$. SEM images showed that $\mathrm{NaOCl}$ and $\mathrm{MI}$ provided surface changes. EDS analysis revealed the presence of oxygen for specimens in contact with both MI and $\mathrm{NaOCl}$ solutions, which might suggest that the two solutions promoted the oxidation of the surfaces, thus leading to spot corrosion. Within the limitations of this study, it may be concluded that the $\mathrm{NaOCl}$ and $\mathrm{MI}$ may not be suitable for cleaning of RPD.
\end{abstract}

Key Words: removable partial denture, denture cleansers, roughness, scanning electronic microscope (SEM), energy dispersive X-ray spectrometry (EDS).

\section{INTRODUCTION}

Proper cleaning of removable partial dentures (RPD) is important to maintaining a healthy oral mucosa. Microbial biofilm on tissue and denture surface is a significant cofactor in the pathogenesis of denture stomatitis (1). Surface roughness may contribute to the positively correlated rate of microbial colonization, the adhesion of microorganisms and biofilm maturation on surfaces (2-5).

The roughness of the acrylic resin surfaces is an important factor, since the adhesion of microorganisms to a surface is a prerequisite for the colonization of that surface. Surface irregularities increase the likelihood of microorganisms remaining on the denture surface after the prosthesis has been cleaned (6).

Webb et al. (7) showed that brushing alone is not as effective as chemical cleansing in reducing denture biofilm or in preventing denture stomatitis associated with Candida. Immersion denture cleansers can be divided into 5 classes: alkaline peroxides, alkaline hypochlorite, diluted acids, disinfecting agents, and enzymes $(1,8)$. The combination of mechanical and chemical methods seems to be the best choice for denture

Correspondence: Profa. Dra. Valéria Oliveira Pagnano, Departamento de Materiais Dentários e Prótese, Faculdade de Odontologia de Ribeirão Preto, USP, Avenida do Café, S/N, Monte Alegre, 14040-904 Ribeirão Preto, SP, Brasil. Tel: +55-16-3602-4795. Fax: +55-16-3633-0999. email: valpag@forp.usp.br 
cleaning (8-10).

Removable partial denture frameworks are usually fabricated from cobalt-chromium alloys. Because these alloys can corrode or stain as a result of surface contact with the chlorine or oxygen present in some commercial cleansers, RPD wearers must be instructed about the correct selection of cleansing agents for their sanitization regime $(11,12)$.

Jagger, Harrison (13) and Peracini et al. (14) observed that the patients do not receive correct professional instructions on how to clean their dentures. They overclean the prostheses, using homecare products, which could cause harmful effects. One of ideal denture cleanser properties is not to cause deleterious effects to the denture materials. It is a critical point when considering the use of the products routinely indicated for complete dentures to clean RPD. The alkaline hypochlorite use in successfully concentration to resin bases can be harmful to the cobalt-chromium frameworks. These undesirable effects can be either tarnish (surface discoloration) or corrosion (surface pitting) (15).

The roughness of denture base acrylic resin when exposed to denture cleansers has been widely reported $(11,16,17)$. However, little information is available on the influence of denture cleansers on the surface of RPD. In view of the importance of a correct orientation to the patients concerning the more suitable auxiliary cleansing methods, the purpose of this study was to evaluate the effect of different denture cleansers on the surface stability of RPD. The null hypothesis tested was that the effects of the different solutions are not harmful for both alloys.

\section{MATERIAL AND METHODS}

The information of the products used in this study are presented in Table 1. Two cobalt-chromium alloys (Dentsply Ind. e Com. Ltda, São Paulo, SP, Brazil) and (Vera PDI; Aalba Dent. Inc., Cordelia, CA, USA) were used. Seventy disc-shaped wax patterns $(12 \mathrm{~mm}$ in diameter $\mathrm{x} 3 \mathrm{~mm}$ thick) were obtained using a fluorocarbon resin (Teflon; Dupont, Wilmington, DE, USA) matrix. Thirty-five wax patterns were sprued, invested and casted in each alloy according to manufacturers' instructions. The product informations are presented in Table 1. After casting, the specimens were finished with 220, 400 and 600-grit sandpaper (Norton Abrasives; Saint-Gobain, Vinhedo, SP, Brazil) in a polishing machine (Arotec, Cotia, SP, Brazil) under water cooling. In order to simulate RPD, the metallic discs were included in heat-cured acrylic resin using moulds previously prepared from a fluorocarbon resin rectangular matrix ( $38 \mathrm{~mm} \times 18 \mathrm{~mm} \times 4 \mathrm{~mm}$ ). The disc was positioned in the left side of each rectangular mold and the stone (Densite; Dentsply Ind. e Com. Ltda., Petrópolis, RJ, Brazil) was isolated with a thin layer of separating medium (Cel-Lac; S.S. White Artigos Odontológicos Ltda., Rio de Janeiro, RJ, Brazil) before resin insertion. The cure cycle was made in water at $73^{\circ} \mathrm{C}$ for $90 \mathrm{~min}$ and at $94^{\circ} \mathrm{C}$ for $30 \mathrm{~min}$. After processing, all specimens were polished under refrigeration in the same machine used for the metallic discs, followed by polishing cloths and 1- $\mu \mathrm{m}$ diamond suspension (Fortel Ind. Com., São Paulo, SP, Brazil). All the specimens were stored in distilled water at $37 \pm 1^{\circ} \mathrm{C}$ for $50 \pm 2 \mathrm{~h}$, to reduce the residual monomer.

The specimens were randomly distributed into the 7 groups for each alloy, each group consisting of 5 samples, according to the alloy type and cleansing treatments tested. The initial surface roughness of metal and resin were measured in micrometers in 3 different areas of each specimen by using a surface analyzer (Surftest SJ-201P; Mitutoyo Corporation, Tokyo, Japan) calibrated at sample length of a $0.8 \mathrm{~mm}, 4.0$ $\mathrm{mm}$ percussion of measure, and $0.5 \mathrm{~mm} / \mathrm{s}$. The mean
Table 1. Composition of materials used in the study.

\begin{tabular}{lcc}
\hline Material & Composition & Batch numbers \\
\hline Co $(64.8 \%), \mathrm{Cr}(28.5 \%)$, & \\
MoguDent $(5.3 \%), \mathrm{Si}(0.5 \%)$, & 660757 \\
Mn $(0.5 \%), \mathrm{C}(0.4 \%)$ & \\
Vera PDI & Co $(63.5 \%), \mathrm{Cr}(27 \%)$, Mo $(5.5 \%)$ & 970623 \\
Periogard & $0.12 \%$ chlorhexidine digluconate & BR121 \\
Cepacol & Cetylpyridinium chloride 0.500 mg & 800425 \\
Corega Tabs & Sodium perborate and enzyme & LMC267V4 \\
Medical & Citric acid & HE-03 \\
Interporous & & F1109L5 \\
Polident & Sodium perborate and enzyme & \\
\hline
\end{tabular}


roughness of each specimen surface was calculated. Weight was recorded using a high-precision balance (Model A200DS; Denver Instr. Company, Denver, CO, USA) that was calibrated before each measurement.

Subsequently to the initial measurements of roughness and weight, the specimens were subjected to the cleaning procedures. The effervescent cleanser solutions were prepared by adding one tablet of each cleanser [Corega Tabs (Stafford-Miller Ind., Rio de Janeiro, RJ, Brazil), Medical Interporous (MST Laboratories AG, Vaduz, Liechtenstein) and Polident (GlaxoSmithKline, Philadelphia, PA, USA)] to $200 \mathrm{~mL}$ of warm distilled water $\left(45^{\circ} \mathrm{C}\right)$ as the manufacturers's instructions. The groups were stored in an oven to maintain the temperature. For storage in the solutions, the specimens were positioned in a device developed to this study. The immersions were performed 180 times, following the time recommended by each manufacturer. Each immersion of Medical Interporous required 15 min, resulting in 2700 min of immersion. In the same way, the time indicated to Polident was 3 min, resulting in $540 \mathrm{~min}$ and the Corega Tabs group resulted in 900 min of immersion ( 5 min each). For the mouthwashes - Periogard (Colgate-Palmolive Indústria e Comércio Ltda., Osasco, SP, Brazil) and Cepacol (Sanofi-Aventis Farmacêutica Ltda, Suzano, SP, Brazil) - $0.05 \%$ sodium hypochlorite and distilled water, the immersion time was fixed in $10 \mathrm{~min}$ for each immersion, resulting in 1,800 min. All solutions were changed every $8 \mathrm{~h}$. After immersion in the respective solutions, each test specimen was washed with distilled water for $10 \mathrm{~s}$. Then, the second measurements of roughness and weight were done in the same way as described for the initial measurements. The difference was calculated.

Table 2. Mean and standard deviation of surface roughness ( $R a$, $\mu \mathrm{m})$ of metal for solutions.

\begin{tabular}{ll}
\hline Solutions & Mean (SD) \\
\hline Distilled water & $0.054(0.017) \mathrm{a}$ \\
Sodium hypochlorite & $0.070(0.019) \mathrm{a}$ \\
Periogard & $0.062(0.016) \mathrm{a}$ \\
Cepacol & $0.064(0.018) \mathrm{a}$ \\
Corega Tabs & $0.074(0.019) \mathrm{a}$ \\
Medical Interporous & $0.055(0.015) \mathrm{a}$ \\
Polident & $0.065(0.015) \mathrm{a}$ \\
\hline
\end{tabular}

Same letters indicate no statistically significant difference $(\mathrm{p}>0.05)$.
A scanning electron microscope (EVO 50; Zeiss, Cambridge, UK) was used to examine the metal surface changes and tarnishes. Surface composition in these areas of interest was identified using an energy dispersive x-ray spectrometry (EDS) (500 Digital Processing; IXRF Systems, Houston, TX, USA). One specimen of each group was randomly chosen to be analyzed by SEM and EDS after immersion in the cleansers. Also, one specimen was fabricated specifically for the initial analyses because of the gold sputtering (SCD-050; BalTec, Vaduz, Lichtenstein) necessary to provide a better contrast of the specimens, especially in the resin portion.

Statistical analysis was performed using the SPSS 10 statistical software for Windows (SPSS Inc., Chicago, IL, USA). Two-way ANOVA and Tukey's test were used to determine whether there were statistically significant differences of roughness among the alloys and solutions. All data were analyzed at an alpha level of 0.05 .

\section{RESULTS}

The roughness changes on the metal $(R a, \mu \mathrm{m})$ were recorded as the difference between the average of roughness in each period of time (T0 and T1). The analysis showed that the surface roughness was not influenced by the solutions or the alloys. There was no significant difference between the alloys $(p=0.25)$ or among the solutions $(\mathrm{p}=0.08)$. Although the surface roughness values increased after the immersions, it was not statistic and also clinically significant. The results are presented in Tables 2 and 3.

The results of the heat-polymerized acrylic resin were recorded in the same way as the metal roughness. Two-way ANOVA showed no significant differences among the solutions. There was no significant difference between the alloys $(\mathrm{p}=0.07)$ or among the solutions $(\mathrm{p}=0.44)$. The values are presented in Tables 4 and 5 .

Visual analysis showed that all specimens of the sodium hypochlorite groups, $40 \%$ of Medical Interporous/DeguDent and 60\% of Medical Interporous/

Table 3. Mean and standard deviation of surface roughness (Ra, $\mu \mathrm{m})$ of metal for alloys.

\begin{tabular}{lc}
\hline Alloys & Mean (SD) \\
\hline DeguDent & $0.064(0.017) \mathrm{a}$ \\
VeraPDI & $0.063(0.019) \mathrm{a}$ \\
\hline
\end{tabular}

Same letters indicate no statistically significant difference $(\mathrm{p}>0.05)$. 
Vera PDI groups showed dark tarnishes on the metal surface. Scanning electron microscopy (SEM) analysis of the metal was performed before the treatments and after the immersions. It was possible to note general corrosion for the hypochlorite specimens and (EDS) analysis showed the adhesion of the Medical Interporous solution on the surface, which caused spot corrosion (Figs. 1 and 2). The presence of the oxygen ion in a high concentration in these groups identified by semiquantitative analysis could confirm the visual perception of corrosion. In the other groups, no signs of corrosion

Table 4. Mean and standard deviation of surface roughness ( $R a$, $\mu \mathrm{m})$ of heat-polymerized acrylic resin for the tested solutions.

\begin{tabular}{ll}
\hline Solutions & Mean (SD) \\
\hline Distilled water & $0.071(0.015) \mathrm{a}$ \\
Sodium hypochlorite & $0.060(0.015) \mathrm{a}$ \\
Periogard & $0.061(0.019) \mathrm{a}$ \\
Cepacol & $0.068(0.023) \mathrm{a}$ \\
Corega Tabs & $0.078(0.028) \mathrm{a}$ \\
Medical Interporous & $0.058(0.020) \mathrm{a}$ \\
Polident & $0.071(0.026) \mathrm{a}$ \\
\hline
\end{tabular}

Same letters indicate no statistically significant difference $(p>0.05)$.

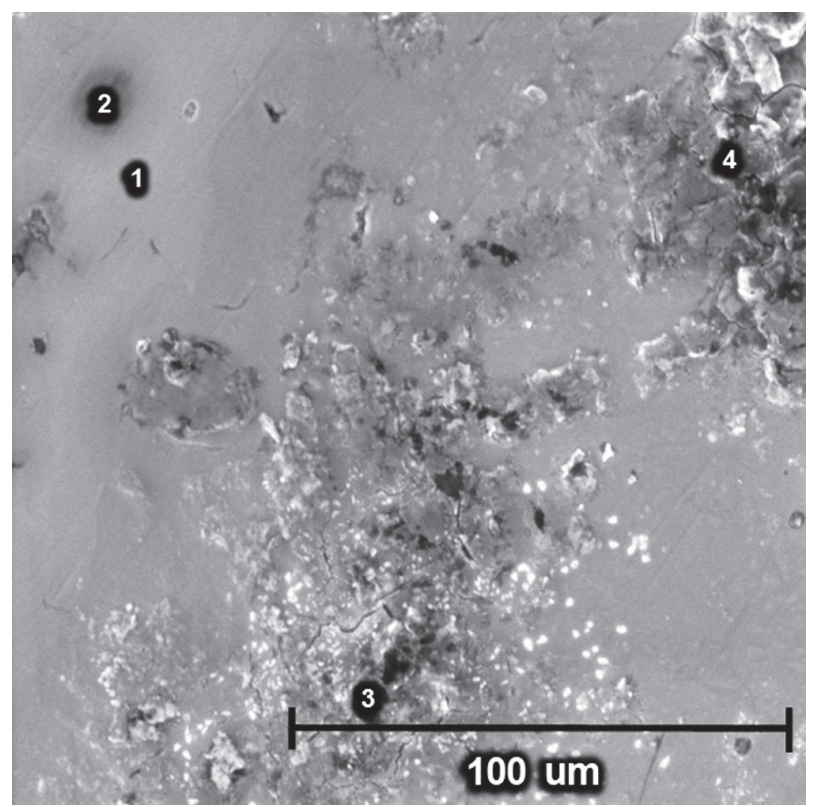

Figure 1. SEM micrograph of a Medical Interporous/Vera PDI specimen. 1: surface without changes; 2: dark spot suggesting organic deposition; 3 and 4: surface change suggesting corrosion. the resin part of the specimens was analyzed by SEM.

\section{DISCUSSION}

The surface roughness of denture materials is of extreme importance becauase they can affect directly or indirectly the adhesion of microorganisms (2-5). For microbial adhesion to occur, it is necessary a minimal roughness of $0.2 \mu \mathrm{m}$, which is the acceptable threshold value (6).

The aim of this study was to evaluate the effects of 6 experimental solutions on the RPD cleaning. Sodium hypochlorite was used at $0.05 \%$, a small concentration with antimicrobial effect found in the literature (9). Sodium perborate-based effervescent tablets (Corega Tabs and Polident) were included in the study in order to compare the methods usually studied. In the acid

Table 5. Mean and standard deviation of surface roughness ( $R a$, $\mu \mathrm{m})$ of heat-polymerized acrylic resin for each alloy.

\begin{tabular}{lc}
\hline Alloys & Mean (SD) \\
\hline DeguDent & $0.076(0.022) \mathrm{a}$ \\
VeraPDI & $0.057(0.019) \mathrm{a}$ \\
\hline
\end{tabular}

Same letters indicate no statistically significant difference $(p>0.05)$.

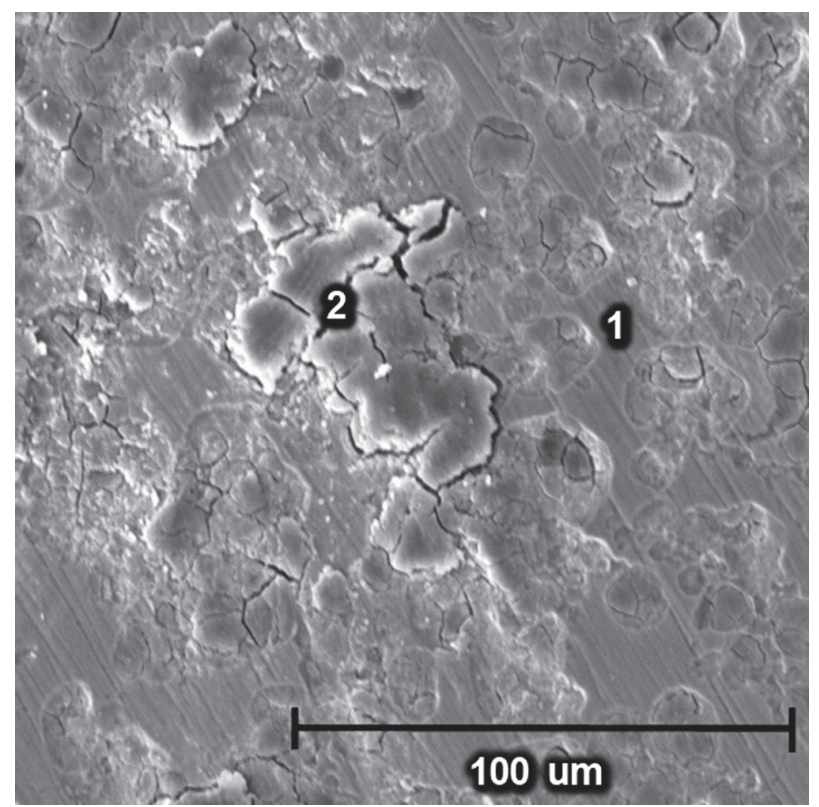

Figure 2. SEM micrograph of a sodium hypochlorite/Vera PDI specimen. 1: surface without changes and 2: surface change suggesting corrosion. 
category, a citric acid-based tablet recently introduced in the market (Medical Interporous) was slected, with the indication of use in metallic components with no deleterious effects. Cepacol and Periogard rinsing solutions were also evaluated for their antimicrobial effects (18-20). Distilled water was used as control. Two Co-Cr alloys with similar compositions were evaluated with the aim to compare the stability of the alloys.

In the current study, there was no significant difference between the alloys and among the solutions when the roughness of the heat-polymerized acrylic resin and the metallic alloys was evaluated. The results of the present study were not in accordance with some studies (17) because the disinfection procedures with sodium perborate did not significantly increase the roughness of heat-polymerized acrylic resin, whereas mean roughness values of all specimens remained relatively close to the threshold limit value. The surface roughness observed after chemical disinfection may have been a result of the combination of the soaking temperature and the oxygen-liberating solution.

Through visual analysis to verify the presence or absence of tarnishes, it was noted that all the specimens of the alloys/sodium hypochlorite groups presented stains of the metallic surface. In addition, $40 \%$ of Medical Interporous/VeraPDI and $60 \%$ of Medical Interporous/ DeguDent groups have also presented surface spotting. For the other groups the presence of tarnishes was not observed. The tarnishes suggest that corrosion occurred and that the solutions are not suitable cleansers because they were harmful to these alloys.

Complementary analyses by SEM and EDS were used to evaluate the surface texture and permitted a microscopic visualization of the surfaces to identify the deleterious effects promoted by the solutions. As EDS is a surface analysis technique, the peak intensities can be associated with the amount of the elements in the surface neighborhood. In this sense, sodium hypochlorite was shown to have a more pronounced oxidizing effect than the Medical Interporous solution, since the oxygen peak for the sodium hypochlorite/VeraPDI specimen was larger than that of the Medical Interporous/Vera PDI specimen. It could be observed generalized and pitting corrosions in the specimens immersed in sodium hypochlorite. Even in a low concentration $(0.05 \%)$ as suggested by Barnabé et al. (9) for complete dentures, sodium hypochlorite was capable of causing surface damage (Fig. 2), in accordance with most of the works found in the literature, which do not indicate its use in prosthesis with metallic components $(15,20,21)$. Although the manufacturer of the Medical Interporous tablets has indicated its use in metallic structures, this tablet led to surface corrosion of the evaluated metallic alloys. It has been observed that such corrosion occurred by the prolonged deposition of the solution on the metal, since rinsing with running water after the immersion, as indicated by the manufacturer, was not sufficient to remove the thin film formed on the specimens (Fig. 1). It is believed then that the product had a continuous effect over the specimens even after they were removed from the solution. Therefore, the results obtained in this study suggested that the instructions for use should be reformulated not only with rinsing in running water but also with recommendation for brushing after the immersion. If the product were completely removed, corrosion would probably not occur.

The mouthrinses used in this study did not cause any deleterious effects to the denture components. It is important to note that the artificial teeth were not examined and studies have suggested that chlorhexidine may cause tarnishes in these components $(15,21,22)$.

The objective of this study was to use commercial products to be auxiliaries to dentures cleaning and not substitutes to the mechanical method. It was not the intention either to assess the antimicrobial effects of the solutions. The daily investment is also an important factor to be considered. Studies evaluating the capacity of diluted mouthrinses in eliminating microorganisms should be developed in an attempt to offer alternatives to reduce costs to patients.

Within the limitations of this study, it may be concluded that the use of $0.05 \%$ sodium hypochlorite and citric acid-based tablets caused harmful effects to the metallic components of the RPD such as tarnishes and spot corrosion. Although these solutions did not cause any significant roughness change in the cobalt-chromium alloys or in the heat-polymerizing resin, they may not be indicated for cleaning of RPD. The other tablets and the mouthrinses were proven suitable for this proposal, when surfaces aspects were tested.

\section{RESUMO}

As próteses parciais removíveis (PPR) exigem higienização específica e a associação da escovação com imersão em soluções químicas tem sido o método mais recomendado para controle do biofilme. Entretanto, os efeitos destas soluções não são amplamente reportados em componentes metálicos. Este estudo avaliou o efeito de diferentes agentes de higienização na superfície 
dos componentes de uma PPR. Foram confeccionados 5 espécimes (disco metálico de $12 \times 3 \mathrm{~mm}$ centralizado em uma tira de resina com $38 \times 18 \times 4 \mathrm{~mm}$ ) para cada situação experimental: 6 soluções [Periogard (PE), Cepacol (CE), Corega Tabs (CT), Medical Interporous (MI), Polident (PO), hipoclorito de sódio 0,05\% (HS) e água destilada (AD) como controle)] e 2 ligas de cobalto-cromo [DeguDent (DD) e Vera PDI (VPDI)] foram utilizadas para cada situação experimental. Foram simuladas imersões de 180 dias. As aferições de rugosidade $(R a, \mu \mathrm{m})$ tanto em porção metálica quanto em resina acrílica termopolimerizável foram submetidos ao ANOVA e ao teste de Tukey. As alterações superficiais e manchas foram examinadas por meio de microscopia eletrônica de varredura (MEV). Áreas de interesse foram submetidas à espectrometria por energia dispersiva por raios X (EDS). Visualmente, puderam ser verificadas manchas nas superfícies metálicas quando utilizados HS e MI. A rugosidade dos materiais não foi afetada pelas soluções $(p>0,05)$. As fotomicrografias evidenciaram que HS e MI ocasionaram alterações superficiais. As análises de EDS revelaram a presença de oxigênio nos grupos HS e MI, o que pode sugerir que estas duas soluções causaram oxidação das superfícies, provocando pontos de corrosão. Dentre as limitações do presente estudo, pode-se concluir que estas soluções não são apropriadas para a higienização das PPR.

\section{REFERENCES}

1. Budtz-Jørgensen E. Materials and methods for cleaning dentures. J Prosthet Dent 1979;42:619-623.

2. Taylor R, Maryan C, Verran J. Retention of oral microorganisms on cobalt-chromium alloy and dental acrylic resin with different surface finishes. J Prosthet Dent 1998;80:592-597.

3. Nikawa H, Jin C, Makihira S, Egusa H, Hamada T, Yamashiro $\mathrm{H}$, et al.. Biofilm formation of Candida albicans on the surfaces of deteriorated soft denture lining materials caused by denture cleansers in vitro. J Oral Rehabil 2003;30:243-250.

4. Glass RT, Bullard JW, Conrad RS, Blewett EL. Evaluation of the sanitization effectiveness of a denture-cleaning product on dentures contaminated with known microbial flora. An in vitro study. Quintessence Int 2004;35:194-199.

5. Berger JC, Driscoll CF, Romberg E, Luo Q, Thompson G. Surface roughness of denture base acrylic resins after processing and after polishing. J Prosthodont 2006;15:180-186.

6. Bollen CM, Lambrechts P, Quirynen M. Comparison of surface roughness of oral hard materials to the threshold surface roughness for bacterial plaque retention: a review of the literature. Dent Mater 1997; 13:258-269.

7. Webb BC, Thomas CJ, Whittle T. A 2-year study of Candidaassociated denture stomatitis treatment in aged care subjects. Gerodontology 2005;22:168-176.

8. Nikawa H, Hamada T, Yamashiro H, Kumagai H. A review of in vitro and in vivo methods to evaluate the efficacy of denture cleansers. Int J Prosthodont 1999;12:153-159.

9. Barnabé W, Mendonça Neto T, Pimenta FC, Pegoraro LF, Scolaro JM. Efficacy of sodium hypochlorite and coconut soap used as disinfecting agents in the reduction of denture stomatitis, Streptococcus mutans and Candida albicans. J Oral Rehabil 2004;31:453-459.

10. Paranhos HFO, Silva-Lovato CH, Souza RF, Cruz PC, Freitas KM, Peracini A. Effects of mechanical and chemical methods on denture biofilm accumulation. J Oral Rehabil 2007;34:606-612.

11. Rodrigues Garcia RC, Joane Augusto de S Jr, Rached RN, Del Bel Cury AA. Effect of denture cleansers on the surface roughness and hardness of a microwave-cured acrylic resin and dental alloys. J Prosthodont 2004;13:194-199.

12. Ribeiro DG, Pavarina AC, Giampaolo ET, Machado AL, Jorge JH, Garcia PP. Effect of oral hygiene education and motivation on removable partial denture wearers: longitudinal study. Gerodontology 2009;26:150-156.

13. Jagger DC, Harrison A. Denture cleansing - the best approach. $\mathrm{Br}$ Dent J 1995;178:413-417.

14. Peracini A, Andrade IM, Paranhos H de F, Silva CH, de Souza RF. Behavior and hygiene habits of complete denture wearers. Braz Dent J 2010;21:247-252

15. Backenstose WM, Wells JG. Side effects of immersion-type cleansers on the metal components of dentures. J Prosthet Dent 1977;37:615-621.

16. Da Silva FC, Kimpara ET, Mancini MN, Balducci I, Jorge AO, Koga-Ito CY. Effectiveness of six different disinfectants on removing five microbial species and effects on the topographic characteristics of acrylic resin. J Prosthodont 2008;17:627-633.

17. Machado AL, Breedings LC, Vergani CE, Perez LEC. Hardness and surface roughness of reline and denture base acrylic resins after repeated disinfection procedures. J Prosthet Dent 2009;102:115-122.

18. Menendez A, Li F, Michalek SM, Kirk K, Makhija SK, Childers NK. Comparative analysis of the antibacterial effects of combined mouthrinses on Streptococcus mutans. Oral Microbiol Immunol 2005;20:31-34

19. Lessa FC, Enoki C, Ito IY, Faria G, Matsumoto MA, NelsonFilho P. In-vivo evaluation of the bacterial contamination and disinfection of acrylic baseplates of removable orthodontic appliances. Am J Orthod Dentofacial Orthop 2007;131:11-17.

20. Franco-Neto CA, Parolo CC, Rösing CK, Maltz M. Comparative analysis of the effect of two chlorhexidine mouthrinses on plaque accumulation and gingival bleeding. Braz Oral Res 2008;22:139144.

21. André RF, Andrade IM, Silva-Lovato CH, Paranhos H de F, Pimenta FC, Ito IY. Prevalence of mutans streptococci isolated from complete dentures and their susceptibility to mouthrinses. Braz Dent J 2011;22:62-67.

22. Abelson DC. Denture plaque and denture cleansers: review of the literature. Gerodontics 1985;1:202-206.

Received September 30, 2010 Accepted June 1, 2011 